\title{
Introduction to the Special Issue on CAP Reform
}

\author{
Fernando GUIRAO
}

Any scholar dealing with the Common Agricultural Policy (CAP) today, no matter in which field the scholar is working, has to take into consideration a multiplicity of questions and, above all, the longue durée which is involved in this subject. Any mono-disciplinary approach to the subject or one which isolates decisions made at any specific juncture from their subsequent cumulative impact is bound to fail in the attempt to improve our collective understanding of one of the most complex existing public policies. This complexity is not intrinsic to but imposed on the sector. Agriculture was the third economic sector to receive the particular regulatory attention of policy makers within the European Communities. The first was coal and steel under the aegis of the Treaty establishing the European Coal and Steel Community. The second was trade in industrial commodities through the customs union provisions of the European Economic Community (EEC). After the competition policy central to the common coal and steel market and the commercial policy built into the customs union provisions, the CAP was the third successful attempt at a common policy among the Six. Since its inception though, the CAP has been the most significant among the set of existing common policies in terms of the Community's budget, administration, legislative and judicial action. And, for these very same reasons, the most contested one.

The amount of resources devoted to the CAP should not be taken as an indication of how essential this policy is for the population of the European Community. The non-agricultural activity, as well as non-agricultural commodity and service trade within the EEC area and between the latter and the rest of the world, have always been, and will continue to be in the future, much more important for the citizens of the member States of the European Community (EC) / Union (EU) than agriculture. The high amounts of collective resources traditionally devoted to the CAP only show that protectionism is expensive and cumbersome to handle.

Despite the fact that agriculture represented, in 2009, $1.7 \%$ of the combined gross added value of the 27 member States of the European Union (EU27) and 5.6\% of EU27 total active population, CAP expenditure amounted to $41.9 \%$ of the EU budget. ${ }^{1}$ Thus, in spite of agriculture's limited weight in gross domestic product and

1. Gross value added of agriculture, hunting and fishing, at current basic prices and current exchange rates, as a percentage of all branches, and agriculture as a percentage of total employment in 2009, both values according to the European Commission's Eurostat National Accounts and employment (LFS adjusted series) data (http://epp.eurostat.ec.europa.eu/portal/page/portal/national_accounts/data/main_tables and http://epp.eurostat.ec.europa.eu/portal/page/portal/statistics/search_database respectively - last accessed on 8 September 2010). The budget figure is that given under the heading 'Natural resources' (including: market related expenditure and direct aids, as well as rural development, environment and fisheries) as reported in EUROPEAN COMMISSION, General Budget 
employment terms for the whole of the EU, the CAP still deserves careful attention for, at least, a twofold reason. First of all, the size of overall CAP expenditure and its unequal distribution among designated recipients - agricultural producers in the different EU member States - mean that any future budgetary discussion among EU member States will necessarily involve a very lively debate on the agricultural dimension. Secondly, since the EU is the largest world importer and producer of agricultural goods, its policy on agriculture affects producers and consumers worldwide, not only within the EU itself. This implies that, in spite of the reduced importance of the agricultural sector - no matter how it is measured - the CAP plays a large role in conflicts both within the EU and between the EU and the rest of the world.

The desire to dispel war-time memories of hunger, the widely held idea that price instability had provoked the breakdown of the liberal European regimes in the 1930s, the dollar-import-substitution rationale which was particularly strong after Western Europe's balance of payments crisis during the first half of 1947, the strategic electoral value of the agrarian community in most West European countries during the reconstruction period, and the capacity of agricultural producers' organisations to express their immediate interests effectively, led most Western governments, during the late 1940s, to provide emergency support to their domestic producers in order to increase domestic food output. Post-war States resorted to a wide range of procedures among those at their disposal, but the most persuasive one for farmers was, everywhere, State assurance of guaranteed State purchasing of outputs at stable and high prices so that the incomes of agricultural producers and their families would no longer be subject to the variability in market conditions.

The CAP was the instrument which was conceived to further sustain all the six original member States in their common attempts to cover the existing income gap between the agricultural sector and other socio-economic sectors, once all post-war efforts at the modernisation of agricultural production had failed. This explains why the CAP acted through market policies, via price regulation, instead of the alternative system of deficiency payments or direct income support which had been adopted in Britain. The reason for this option was no major secret: in all six founding member States market policies were already central instruments in agricultural policies and the Community adopted this policy pattern not because it was sound but because national policy makers were unwilling to face the social and political consequences of putting agricultural producers under any productivity pressure. ${ }^{2}$

The problem was, however, to determine at what level agricultural prices should be fixed and who should bear the cost of financing the heavy spending consequent upon the decision to guarantee "a fair standard of living for the agricultural population, particularly by the increasing of the individual earnings of persons engaged in

of the European Union for the Financial Year 2009. The Figures, Brussels-Luxembourg, January 2009 , p.9.

2. For a detailed analysis of the circumstances affecting agriculture and leading towards the EEC Treaty, see The Europeanization of agricultural protection, chapter five of A.S. MILWARD, The European Rescue of the Nation-State, Routledge, London, 1992, pp.224-317. 
agriculture". ${ }^{3}$ The exact level of such a guarantee would become the source of conflict between France and the Federal Republic of Germany during the late 1950s and the whole of the 1960s. Negotiations centred on the target price for soft wheat, the key agricultural price to which most other agricultural prices related, which was finally agreed in December 1964. This was the core of the CAP.

Carine Germond explains how the CAP was, at first, a Franco-German agreement which was then transformed into common policy. In line with previous published research which the reader will find referred to in the footnotes of her contribution, Germond shows how the determining force in the formative phase of the CAP was the French government and its ability to impose temporary agreements on its German counterpart, which were then automatically turned into conquered ground from which to launch new demands for further concessions. The Federal Government resisted the originally-proposed price levels because they were below the high domestic prices then applying in Germany but it changed its position at the end of 1964. Germond explains convincingly the circumstances leading to the change of the German attitude. It is clear that had it been left to the German government no common agricultural policy would have been devised but, at the same time, without the German economic support, the Community's agricultural policy would not have been cast in line with previous French practices and policy aspirations. At each French assault, the German government firstly resisted, secondly conceded, and finally ended up realising that what they had given in was translated into French as a completely different concession from the one the Federal government had initially thought it was granting. The origins of the CAP are, in fact, rooted in a mixture of blackmailing, bullying, and confusion.

The CAP started as a simple price support policy for cereal, then extended the system of guaranteed prices to dairy products, beef, veal and sugar, and its intervention mechanisms - not all via price support - ended up encompassing the entire agricultural production of the member States by 1970. In this respect, it is interesting to notice that policy makers limited their decisive protective (socially inclusive) action to agricultural producers, but almost completely forgot the farm workers, those who received their income directly from landowners. This is yet another legacy of the reconstruction times when only producers were well organised. Rainer Fattmann shows, in his introductory research included in this volume, how the agricultural workers progressively formed their own unions in order to pass on their particular goals to policy makers at the Community level. The Europeanization of interest groups as trans-national lobbies was thus not limited to producers, but extended to land workers' unions. Soon, inevitably, agricultural producers and farm workers clashed over the constituent element of the CAP. Although in Italy a certain confusion prevailed for some time, producers and workers were talking a different language. While producers opposed any rationalisation of the CAP in terms of edging agricultural production towards higher productivity levels, farm workers realised that, as was then the case with other workers in industry and services, for their wages to rise they had to linked to increasing productivity.

3. Article 39 (b) of the Treaty establishing the European Economic Community. 
Foreign threats have always served the purpose of further consolidating the CAP according to a certain set of interests. This has always been the case with multilateral trade negotiations under the aegis of the General Agreement on Tariffs and Trade since the Kennedy Round of 1964-67. British EEC membership embodied the danger of interiorising this external pressure, as a Trojan Horse. For this reason, the first enlargement of the European Community was not conceivable until the French government (whether headed by General Charles de Gaulle or Monsieur Georges Pompidou) was completely satisfied with the actual shaping of the Community's policies and institutional design. A fully operational CAP, for instance, which had come into force in July 1967, was not sufficient to open negotiations with the United Kingdom and other applicants standing in the waiting line. The missing link was a FrancoGerman agreement for financing the Community (and thus the CAP) on a permanent basis. The French government's failure to satisfactorily secure the "system of own resources" led to recurrent Community crises, in January 1963, from June 1965 to January 1966, and in November 1967. Only with the definition of the final terms of the Community's "own resources" in April 1970, which were immediately turned into law (acquis communautaire) of mandatory enforcement, could official negotiations leading to the first enlargement of the European Community be initiated, in June 1970.

The CAP was to be paid for out of the common Community budget. This simply means that the financing for market-intervention devices was guaranteed by the Community budget and thus no longer subject to any ad hoc inter-State bargaining. If the CAP was to be paid for out of the common budget and the EEC budget was made of customs duties collected on imports from third countries at the external borders and agricultural duties on imports from non-Community countries of produce subject to common organisation of the market, the Community's agricultural protectionism was to be financed, essentially, by main importers of cheap extra-Community food, that is, the United Kingdom which, once it became an EEC member, would be forced to buy more expensive EEC-made produce in preference to cheaper produce from outside the EEC. The United Kingdom, the largest net importer of cheap food at the time, was allowed to become member of the European Community only if it agreed to share the overall costs of the CAP with the Germans, regardless of the low direct material benefits the British would derive in return. ${ }^{4}$ If the CAP was to be paid for out of the common budget CAP spending would take it all unless the Community devised additional common policies to be financed on the basis of the common budget. The fact that in 1970 CAP expenditure represented ninety per cent of the Community's total budget implied simply that commercial and competition policies were relatively inexpensive and that the Six did not find the establishment of common policies in other directions attractive or feasible.

4. Obviously, the British government expected other benefits - in the form of industrial exports to the then very dynamic EC markets - in return for British membership. The British government's own overall assessment of pros and cons of the British EC membership is Britain and the European Communities: An Economic Assessment, Her Majesty’s Stationery Office, London, 1970. 
The contribution by Robin M. Allers shows the limits of EC membership applicants' ability to challenge the Community's acquis communautaire, the "sacred cow" referred to in the title. Allers addresses two different but intrinsically interconnected matters. Firstly, membership applications are very complex multi-level processes, which exceed the bounds of technical dossiers and go deep into political, social and cultural perceptions. Secondly, precisely because membership applications are so complex, the Community's member States impose upon themselves relatively strict limits and negotiation margins. Notwithstanding this, to my knowledge, no other government having negotiated with the European Community for accession has ever been treated as favourably as the Norwegian. After reading Allers' contribution, readers will certainly ask themselves what else the Community could have granted to the Norwegian government in order to assure a favourable outcome at the September 1972 referendum. I am afraid that the answer to this question might not lie in the final terms of the accession agreement but in both a deeply-rooted popular méfiance towards continental Europe which perhaps has to be explained from a culturalhistory perspective, and a widely held idea, even today, that the "Norwegian way of life" can only lose out if entangled in regulatory schemes in which there is no direct Norwegian control over fundamental issues (such as rural and dispersed areas, fisheries, natural resources, welfare levels, and environmental standards). In 1972, the crucial question at stake and under debate was, in my view, how effectively a small population like that of Norway (almost four million at the time) believed that their vital interests could be secured.

The reasons for the continuous tolerance for CAP (mal)practices beyond the 1960s are hard to explain. Obviously, pressure from the producers' corner continued to exist because they continued to be incapable of sustaining their then levels of income by means of their own productive activity. The system of politically-determined guaranteed prices was designed to shield even the least efficient of the Community's producers. Despite the fact that farmers were no longer crucial from an electoral point of view, they constituted the ministers' own personal constituencies. Thus, national ministers of agriculture continued to defend their own constituency at the cost of the rest of their country's population. In addition, from a broader, national cabinet perspective, agricultural prices as set by the corresponding sectoral ministerial council continued to be the best mechanism to capture part of the State funds that had originally been transferred to the Community. For most governments, the simplest way to present the benefits of Community membership to their electorate was by referring to cash flows entering the country from the Community coffer. The CAP offered the main single budget item from which all governments benefited, without exception. The truth was, however, that for most of these same countries, the total costs incurred by their national consumers and taxpayers surpassed the total benefits received by their food producers. ${ }^{5}$ Consumers were not yet sufficiently organised and some degree of patriotic consumption persisted everywhere. The deep (although distant) rural roots

5. INTERNATIONAL MONETARY FUND (IMF), The Common Agricultural Policy of the European Community. Principles and Consequences, Occasional Paper No.62, IMF, Washington DC, 1988, p. 40. 
of the Western European industrial societies, the increasing romanticising of life in the countryside by populations heavily hit by urbanisation, environmental deterioration, increasing daily stress, and unemployment during the 1970s and 1980s, must, no doubt, have played a role in explaining the high level of tolerance that, in general, Western European populations were willing to offer to agrarian protectionism.

What responsibility should be attributed to the Commission in designing, building and consolidating a market-intervention system which was irrational from a strictly economic point of view? Previous historical research has shown that consideration of the way institutions operate and their legal (or ruling) frameworks improves our understanding of the Community's historical evolution. In this case, there is little doubt that the Commission played a fundamental role in setting up the CAP ${ }^{6}$ Consequently, when facing the reform process, many could be tempted to think that the importance of the CAP for the Commission remained constant and unchallenged. It should have guaranteed the Commission, at least in appearance, executive power and huge amounts of funds to be administered from its Brussels headquarters. Furthermore, significantly in a long-term perspective, the CAP would have provided the Commission with an effective discourse, particularly at troubled times, in favour of popular allegiance towards the Community: common policies would serve to improve standards of living. Under these circumstances, any serious questioning of the CAP as it existed would have meant a questioning of the Community and the Commission's very raison d'être. I wonder whether after the contribution by Katja Seidel in this volume the previous argumentation should be regarded as simplistic and no longer taken into any serious consideration.

The Mansholt Plan of 1968, named after the then Commissioner of Agriculture, Sicco L. Mansholt, was the first of the Commission's numerous attempts to reform the CAP. A very interesting feature in Seidel's contribution is the vocabulary and terminology used in the late 1960s around the preparation, drafting and public and private defences of the Commission's "Memorandum on the reform of agriculture in the European Economic Community" of 21 December 1968. We find the need to rationalise production and reduce overall costs, to cut down prices, to proceed to a radical transformation of agricultural structures, to accommodate production to changes in markets and demand, to produce high quality produce as general incomes rose, to establish modern agricultural enterprises of minimum size and pursue large cooperative arrangements, to set aside arable land, transforming it partly into woodland and partly into recreational areas in which to expand rural tourism as an alternative source of income, to define a rural development policy and use direct aid to farmers to fund education, retraining, and early retirement schemes. Much was indeed needed to put an end to the cynicism involved - in the words of the then Commissioner for Economic and Financial Affairs, Raymond Barre, as referred to by Seidel - in funding rich farmers while dumping surpluses on third-world markets. The terms used by proreformers in the 1960s do not differ much from those being used in present day de-

6. A.C.L. KNUDSEN, Defining the Policies of the Common Agricultural Policy. A Historical Study, $\mathrm{PhD}$ thesis, European University Institute, Florence, 2001. 
bates, which reflects the lack of radical change in CAP matters, despite twenty years of reform.

The Mansholt Plan of 1968 was rejected by short-sighted governments exactly as was the case with the Mansholt Plan of $1950 .{ }^{7}$ Had the latter been successful, this second plan would have not been necessary. Had the former been successful, the policy nightmare the Community was about to experience would have not entered the story books of European integration. Extreme difficulties started with the "monetary compensatory amounts" or specific "green rates" necessary to offset the effects on domestic prices (and producers' earnings) of exchange-rate variability among EC currencies after August 1969, well before the collapse of the Bretton Woods exchange rate system. They continued with the mounting financing problems in times of recession because of overpriced surpluses, which led to the initiation of tortuous, exasperating and frustrating path towards a never-completed reform of the CAP which caused innumerable conflicts over budgetary contributions. The most significant early episode of the latter phenomenon was a whole decade of BritishCommunity confrontation before the 1984 agreement on the "rebate" or British cheque. No reform was possible because, as the reader is already aware, agricultural protectionism, as forged by the Six, was defended against internal threats as effectively as it was against external ones.

Reformers had hardly been welcomed by the CAP's main beneficiaries, i.e., agricultural producers and their supportive governments. Notwithstanding this resistance, since 1992 the CAP has embarked on a process of reform. It is true that since the mid-1980s, there was some experimentation with ad hoc supply controls to discourage production such as maximum production quotas or payments in exchange for setting aside arable land. The various attempts at reform tried to reduce supply without lowering the farming income but they generally failed because of the continuous combined effect of technological progress and high guaranteed prices. For this reason, in 1992, when the Community was no longer able to resist initiating some kind of a reform path with visible results, it had to focus on the price mechanism component of the CAP. The MacSharry Reform of May 1992 (the implementation of which took place during the 1993/94-1995/96 harvest years), named after the then Commissioner for Agriculture, Ray MacSharry, not only tried to move support prices towards lower world levels and compensate farmers with direct aid but also to break the link between subsidisation and production. "Decoupled" payments meant that subsidies were to be paid independently from production; the granting of subsidies was to be made conditional on respect for environmental, food safety and animal welfare standards. Sectoral resistance turned the transition towards a deficiency-payment system, as the preferred instrument of policy intervention in agriculture, into a long and expensive journey.

7. R.T. GRIFFITHS, F. GUIRAO, The First Proposals for a European Agricultural Community: The Pflimlin and Mansholt Plans, in: GRIFFITHS, B. GIRVIN (eds.), The Green Pool and the Origins of the Common Agricultural Policy, Lothian Press, London, 1995, pp.1-19. 
The announced shift to direct payments, price cuts, and drops in storage of food and dumping of food on world markets was countered by other hidden forms of support, with the net result that the "producer support estimate" (PSE) for the EU15 increased from 1995 to 2003 to a level slightly below $40 \%$ of total farm receipts, double U.S. levels, rather than decreasing. ${ }^{8}$ Admittedly, OECD data on PSE showed that many countries - Japan, Korea, Iceland, Norway and Switzerland - misbehaved even more than the European Union. The singularity of the latter's misbehaviour is first the size of the sector and thus the world-wide effect of its decisions and secondly, its worldwide ambitions. The 1992 project that held a united Europe to be a powerful contributor to improving the world economy and its regulatory mechanisms proved to be a pipe dream. The prospect of the Eastern Enlargement, which raised the number of farms from seven to thirty million and farmland from 130 to 170 million hectares, finally forced a deeper reform upon the EU. ${ }^{9}$ It was in 2003 that the EU definitively changed its manner of supporting the farming sector, with the progressive abandonment of subsidies to production (market regulation devices) in favour of direct aid (income support). It was not only that the intervention changed but also that in part it was re-nationalised, since decoupled payments were to be implemented differently by each member State. It has only been recently, since 2005 , that the majority of subsidies have been in the form of decoupled payments.

What were the principal drivers for such a U-turn change in the CAP? There seems to have been a combination of domestic as well as external pressures, the relative significance of which is the subject of much dispute, even among the contributors to this special volume. Contemporary observation of the public features of CAP reform is not sufficient to enable historians to evaluate this process properly. The remaining contributors to this volume, political scientists and economists, come to the historian's assistance in this task. They all focus on providing a better understanding of the process of change and continuity which characterised CAP reform, like any other substantive public-policy reform. Political scientists have long discussed the nature of the changes under the CAP's slow but progressive transformation. In essence, the core of the dispute is whether change is induced because the ideological foundations - underlying ideas - had essentially evolved, or whether change has resulted from a cumulative process of incremental adaptation to an evolving environment. The fundamental question here is not the speed of the transformation but where the CAP is heading. Putting it in very simplistic terms, the question would be: Should a reformed $\mathrm{CAP}$ be a different policy to address future new challenges, or will the CAP simply continue a process of slow adaptation to a hostile environment until it ultimately

8. ORGANIZATION FOR ECONOMIC COOPERATION AND DEVELOPMENT (OECD), Economic Policy Reforms. Going for Growth, Paris, March 2005, p.71. PSE is an improved measurement technique developed by economists at FAO and OECD to measure the degree of government intervention in various agricultural commodities across countries.

9. Number of holdings taken from EUROPEAN COMMISSION, Agriculture in the European Union. Statistical and Economic Information 2002, February 2003, Table 2.0.1.2 (Basic data - key agricultural statistics) available at http://ec.europa.eu/agriculture/agrista/2002/table_en/agri.pdf (last accessed on 31 October 2010). 
becomes extinct, like the dinosaurs during the Cretaceous period? Chris Elton emphasises the ideational side of the reform, Adrian Kay and Robert Ackrill the "incremental hypothesis" and finally, Mark Spoerer the material, "the sober results of the cost side".

Elton defines a shift of the paradigm defining the CAP beginning with the appointment in 1985 of a new Commission under Jacques Delors and being largely completed with the 1992 reform. A paradigm is defined as the combination of a set of goals carried out by a set of instruments, establishing a logic connection between ends and means. In an exercise which will be much appreciated by cultural historians, Elton examines how ideas progressively materialised in a new policy discourse which served to delegitimize certain old policy instruments and goals, in order to enhance others or launch new ones with the final objective of securing the CAP's key original values. In Elton's article ideas, rather than material interests, are the drivers of policymaking. I must confess to the reader that despite my not sharing what the author defines as the key economic, social and cultural values of the original design of the CAP, I do share his main conclusions. Firstly, from 1985 to 1992 the CAP had to be adapted to the paramount objective of securing the Single Market and the European Union. The exact degree of adaptation actually accomplished is a question still subject to some dispute. Secondly, there was a general recognition that expanding agricultural production alone to support comparative incomes and maintain traditional rural life was successfully contested and progressively replaced by the acknowledgement "that rural norms could only be upheld within a multidimensional policy framework". "In practice", concludes Elton,

"the paradigm shift became evident in the changing role of farmers, the restructuring of farm income support and the greater recognition of the cultural and environmental value of the countryside and rural areas".

The farmers' multifunctional role, as providers of some of the new public goods affecting the environment, the landscape, animal welfare, and assistance to less developed countries - that modern societies appreciate and are willing to pay for, became the key feature of CAP's new paradigm.

Kay and Ackrill do not find evidence of any paradigmatic episodes of change in the long process of CAP reform. In fact they are much more interested in searching for a more multi-dimensional account of CAP reforms. According to them, policy changes do not require the previous modification of any paradigm. Change happens as a cumulative process of small transformations. Single fine-tuning events might not threaten any of the fundamentals of the original policy but when placed together with many others and after their collective cumulative effect they may well lead to a significant transformation of the actual policy. The complexity of the CAP - a policy with contradicting policy goals encompassing many different commodities and using a variety of policy instruments - imposes on Kay and Ackrill a complex analytical tool. In analysing CAP reforms, they analyse policy responses with reference to various elements and policy levels: goals, objectives, settings, instrument logic, mechanisms or instruments, and instrument calibration. Following this multi-level me- 
thodology the authors are able to explain how change and continuity occur simultaneously: while the goal of supporting farming incomes still holds (the element of continuity) it has required first an adaptation of the original instruments transferring resources to producers and subsequently new ones (the elements of change). They also placed the responsibility for change on budget and international-trade constrictions. Other concerns, such as those concerning animal welfare and quality and safety in food supply or environmental concerns, Kay and Ackrill argue, seem not to be decisive. In these authors' view, the CAP in 2010, due to the process of incremental endogenous adjustments that they are able to present in their article, "bears little resemblance indeed to that of the 1970s".

The provisional conclusions reached by Spoerer are also simple but telling:

"From an economic point of view, the piecemeal reforms of the 1980s seem to have had more impact on the protective effects of the CAP than the MacSharry reform".

As a matter of fact, after 1992 guaranteed prices were lowered but the volume of direct payments to producers was kept at historically recorded income levels. The net result was that the cost of protection was transferred from consumers to taxpayers. Spoerer clearly sits with the "incremental change" thesis, if limited to the period previous to 1992, and does not see any "material" impact of Elton's "paradigm change" during the 1990s. In doing so, he provides additional support to the claims of non-governmental organisations, $\mathrm{OECD}$, and most third parties at on-going negotiations at the World Trade Organisation (WTO) that the European Union did not drive down the level of protection and support to its agricultural producers as announced by the 1992 reform package. ${ }^{10}$

Spoerer does not present his as the only way of measuring the overall impact of the CAP. Notwithstanding this, I can assure the reader that any future evaluation of the CAP will require taking Spoerer's methods and information into serious account. All the diplomatic duels that historians are willing to cleverly reconstruct, on the basis of tons of documents hidden in numerous archives and written in different languages, and which ended up in price agreements, generated a bill much higher than the exclusive Community-budget cost, which has been borne by consumers and taxpayers within the common market, as well as by agricultural producers world-wide. The long-term implications of specific agreements should no longer stand outside historians' analyses. The CAP can no longer be approached in isolation from its long-term and worldwide implications.

Most contributions to the present volume coincide in referring to how pro-marketers' proposals in agriculture have always met with opposition. The initial establishment of the CAP and the subsequent attempts at its reform pushed the Community almost to the brink of collapse on several occasions. In order to escape obvious

10. Since 1999 Oxfam, which is the leading non-governmental organisation critical of the forms of agricultural protection as carried out in the EU and the United States, has produced a number of reports denouncing the way rich countries' agricultural subsidies damage livelihoods in the developing world. See a complete list at http://www.oxfam.org.uk/resources/policy/trade/index.html. 
difficulties, the EC governments disregarded all the opportunities that they had for face-saving reform. The Kennedy Round (1964-67) was the first one before the CAP became fully operational; the Mansholt Plan of December 1968 the second, once the first properly CAP-policy induced structural-surpluses problem surfaced; and, finally, enlargement negotiations (1970-72) once the exchange-rate fluctuations in the autumn of 1969 had anticipated the high costs involved in the setting of common prices in different currencies whose relative prices were no longer stably fixed. Subsequently, the episodes of the British rebate from 1974 to 1984; the obvious excesses in the dairy sector which led to the first production quotas to be imposed in 1984 and the introduction of a certain degree of financial co-responsibility for output surpluses; the single market programme which came into force in July 1987 and implied the first overall revision of the 1957 foundational Community agreements; the unpleasant episodes of "mad cows" and "sick chickens" of the late 1980s; the Treaty on European Union signed in Maastricht in February 1992 which meant a proper re-foundation of the European Community; the MacSharry Reform of May 1992 which could have implied the re-foundation of the CAP; the GATT Uruguay Round of multilateral negotiations (1986-94); the constant pressure towards reform exercised by the European Commission since 1968 and the permanent disputes among EC member States over the common budget since the system of "own resources" was established in early 1970; or the first WTO multilateral trade negotiations, the Doha Round, since November 2001, at the time when the divergence of the economies of Europe and of the European Union with respect to the most dynamic Western and Eastern world economies was increasing most rapidly, have provided the "moments of truth" for policy makers to proceed to the complete redefinition of a common policy that has, simply, never delivered. ${ }^{11}$

\section{Today's CAP claims to be a "new CAP". According to the Commission,}

"[T] he aim [of the new CAP] is for farmers to produce what the market wants, become more competitive and give better value for consumers and taxpayers, while at the same time benefiting from stable incomes". ${ }^{2}$

Despite the fact that consumers and taxpayers have been put at the forefront of the new policy's objectives, no change can yet be perceived. The forthcoming budgetary negotiations among the 27 member States of the EU may continue to lower the overall share in the EU budget of total expenditure on agriculture (market related expenditure and direct aids, as well as rural development, environment, and fisheries). Notwithstanding this, I am afraid that EU taxpayers will not see their burden alleviated as national and regional budgets are taking increasing care of supplementary measures of support in favour of food producers. In addition, as of today, the CAP is completely

11. The 'moment of truth' metaphor has been borrowed from J. DELORS, The Single Act and Europe: A moment of truth, Office for Official Publications of the European Communities, Luxembourg, 1986.

12. Pierre Bascou, Head of the Economic Analysis of EU Agriculture Unit in the European Commission's Directorate-General of Agriculture and Rural Development in EUROPEAN COMMISSION (EUROSTAT), Getting the price right. Focus on price statistics, in: $\sum$ Sigma The Bulletin of European Statistics, 2(2007), p.51. 
powerless to impose any price discipline given the decreasing relevance of production costs in final consumer prices. Under the on-going reform prices for consumers of agricultural and food products have actually increased while farmers complain loudly about the constant erosion of the prices they receive at production level. In Barcelona, for instance, prices vary up to $609 \%$ from food producers to final consumption. ${ }^{13}$ Apparently the only beneficiaries of the reform so far seem to be the intermediaries along the value chain: the food-processing industry, distribution channels, supermarket chains, and retailers, but definitely not the consumer.

Let me conclude this introduction by underlining that the contributions to the present volume illustrate the benefits but also the limits of inter- and multi-disciplinary approaches. Frequently an inter-disciplinary study consists of a series of research pieces, each one of them perfectly mono-disciplinary, set next to one another. This time, at least, mono-disciplinary studies are in dialogue with each other and take each other's main arguments into account. The final drafts submitted, peer-reviewed and approved for publication were written by taking into consideration the rest of the contributions to this volume. In this sense they all differ greatly from their first drafts. As my co-editors explain in their preface, two different workshops took place to guarantee inter-disciplinary discussions, in Paris and Maastricht in May 2009 and April 2010 respectively. Notwithstanding this cross-disciplinary dialogue, the truth is that some historian might find analytical, methodological and terminological complexities in some of the contributions to the present volume. For this reason, it is clear that without the JEIH Editorial Board's firm commitment towards the promotion of inter-disciplinary approaches some of these articles would have not been published in a journal addressed mainly to historians.

It is exceptional to find a scholar who is equally competent as a historian, economist and political-scientist, all at once. I have known only one: Alan Steele Milward, who sadly left us recently, on the $28^{\text {th }}$ of September 2010. May these words serve as public recognition of the uniqueness of his scholarly talent and this volume, the $32^{\text {nd }}$ of the series, as the JEIH Editorial Board members' collective homage to one of its founding members.

13. Prices registered during the week of 11 to 17 October 2010 for first category beef; see Gobierno de España, Ministerio de Industria, Turismo y Comercio, Secretaría de Estado de Comercio Exterior; for prices at origin see Precios origen destino en alimentación (http://www.comercio.mityc.es/ comercio/bienvenido/NovedadesLicitaciones/Precios+Origen+Destino/pagPreciosOrigenDestinoAlimentacionCambio.htm) and for price oscillations among cities in Spain and at retail level within the same city see data from the Observatorio de Precios (http://www.observatorioprecios.es/ObservaPrecios/Inicio.htm?in=0). Both data bases accessed on 31 October 2010. 


\section{The Agricultural Bone of Contention: The Franco-German Tandem and the Making of the CAP, 1963-1966}

\section{Carine GERMOND}

Agriculture is one of the economic sectors where the process of European integration has been carried furthest. Mentioned in very broad terms in the Rome Treaty of 1957 establishing the European Economic Community (EEC), the Common Agricultural Policy (CAP) was gradually set up during the 1960s. In January 1962, the Common Market countries agreed that the CAP would be organized around the core principles of market unity, Community preference and financial solidarity. In the first half of the 1960s, common prices for each product were adopted and common market organisations created. The common agricultural market became fully implemented in the summer of 1967.

The creation of a common agricultural policy posed specific problems for France and Germany. As one of the principal producers and exporters of agricultural products, France was the state which had most to gain from the formation of a common agricultural market. In the early 1960s, agriculture remained a key economic sector. About 20 percent of the active population worked in that sector and agriculture represented around 10 percent of France's gross domestic product. Hence, when Charles de Gaulle returned to power in 1958, agricultural integration became "a sine qua non condition of France's participation to the EEC". ${ }^{1}$ Thanks to the CAP, de Gaulle hoped to adapt France's industrial and agricultural sectors to the new conditions of trade and competition in the Common Market, ${ }^{2}$ to solve overproduction and social problems in agriculture, ${ }^{3}$ and finally to maintain France's economic parity with Germany - a prerequisite to safeguard its senior position in the Franco-German tandem. For the Federal Republic of Germany (FRG), a major agricultural importer, the CAP threatened to disrupt the German traditional commercial links with third countries, where the FRG bought agricultural commodities and traded manufactured goods. Thus, the German dilemma was to continue buying agricultural commodities to its traditional clients while guaranteeing a certain preference to its EEC partners in its own market. ${ }^{4}$ The CAP also represented a challenge for the highly subsidized and relatively inefficient German agriculture. In addition, although farmers encompassed

1. C. de GAUlle, Mémoires d'espoir, t.I, Paris, Plon, 1970, p.167. See also M. COUVE DE MURVILLE, Une politique étrangère (1958-1969), Plon, Paris, 1971, p. 313.

2. E. PISANI, Le Général indivis, Albin Michel, Paris, 1974, p.63.

3. W.F. ROY, France, Germany and the New Europe 1945-1967, Stanford University Press, Stanford, 1968, p.287.

4. Archives Diplomatiques, Ministère des Affaires étrangères [AD/MAE], Europe [EU] 1961-1970, sous-série [s/s RFA], vol.1552, A. de Saint-Mleux à M. Couve de Murville, Munich, 16.03.1966. 